\title{
Macroeconomic Analysis of Interest Rate and Economic Growth in Nigeria: A Time Series Approach
}

\author{
Miftahu Idris \\ Department of Economics, Taraba State University, Jalingo, Nigeria
}

Email address:

miftahu4real12@gmail.com

\section{To cite this article:}

Miftahu Idris. Macroeconomic Analysis of Interest Rate and Economic Growth in Nigeria: A Time Series Approach. International Journal of Finance and Banking Research. Vol. 5, No. 4, 2019, pp. 91-104. doi: 10.11648/j.ijfbr.20190504.14

Received: July 3, 2019; Accepted: August 7, 2019; Published: August 28, 2019

\begin{abstract}
This study examines the impact of interest rate on economic growth in Nigeria using annual time series data spanning 1980 to 2017. This phenomenon is particularly interesting from a theoretical standpoint as well as for the understanding of financial market mechanisms. The Vector Autoregression (VAR) model and the Granger causality test are employed to estimate the model coefficients and measure the causal relationship among the concerned variables. From the VAR-based impulse response function and its corresponding variance decomposition estimates, result shows the existence of negative relationship between interest rate and economic growth in Nigeria. In addition, the Granger causality test indicates the presence of bi-directional causal relationship between interest rate and economic growth. Consequently, monetary authorities should designed and implement interest rate policies that enhance investment and take into cognisance other elements that retard investment progression. To attain the desired growth level in Nigeria, monetary authorities and policy makers should adopt policy measures that are growth oriented and have the potentials to accelerate the economy to higher productivity and sustainable economic growth.
\end{abstract}

Keywords: Interest Rate, Economic Growth, Var Model, Granger Causality, Nigeria

\section{Introduction}

One of the essential element for encouraging a sustainable and inclusive economic growth is through access to financial services including a productive interest rate. Hence, interest rate is a fundamental component of macroeconomic analysis and a significant tool through which the apex banks conduct monetary policy operations. The possible impact of monetary policy can be determined through different monetary transmission channel in which interest rate, inflation, asset prices and exchange rate relate with one another. One of the prominent and effective monetary transmission mechanism is the interest rate. The interest rate has the potentials to impact on the aggregate economy through determining the magnitude of macroeconomic indicators like capital flows, investment, exchange rate and credit demand. Under the financial sector liberalisation in Nigeria, an interest rate policy reform is introduced. The policy reform is expected to enhance the development of financial sector in the country, encourage domestic savings and provides an enabling environment where borrowing funds are accessible at the banking institutions.

Since the global financial crisis, interest rate has been on the low trend (even negative) in various developed countries, as the nominal interest rate lingered around zero. This scenario shows the implication that monetary policies and approaches that are implemented in response to the financial crisis are the reason behind the low interest rate. Given this condition, the whole circumstances would be over if central bank begins to normalise the monetary policies. As the central banks utilise the interest rate as a policy instrument, measuring its implications on output growth is therefore consistent with the bank's policy target and a necessary condition for an effective conduct of macroeconomic policies. Analysis of interest rate is not only meaningful in this contemporary era, but also essential to the understanding of financial intermediation process and the macroeconomic environment in which the central banks operate.

Around the globe, central banks decrease the benchmark interest rate when the productive capacity of the economy is weak; and raises when facing inflationary pressure. This scenario is best known as Tailor rule. The significance of this 
policy adjustment is highly imperative, depending on country's peculiarities. Since the zero lower bound limits the effectiveness of the standard Taylor rule, central banks are presently adopting a set of policies aimed at directly reducing market interest rates and the rate on bank loans. To conduct this operation, interest rates are considered as a monetary phenomenon. It is understood that financial markets of developing and developed countries respond inversely to monetary measures and approaches. Because of the growing needs and desires to attract foreign capital, developing countries would be unwilling to cut interest rates that may reduce the attractiveness of financial assets in the local currency. On the other hand, developed economies may probably encounter further challenges with interest rate becoming very low, thereby depressing the effectiveness of monetary policy.

In Nigeria, macroeconomic policies with regards to interest rate and other essential indicators have been the central focus of public authorities and other policy makers. Even though the economic reform policies introduced in 1980s recorded a number of substantial level of success; particularly the financial sector liberalisation reforms, yet, there are several lingering challenges with interest rate becoming unproductive hence, yielding a devastating effect on the cost of borrowing and the aggregate investment. Various expansionary monetary policies have been implemented to counter the destabilising impact and further stimulates economic activities, but the increased inflationary pressure on the economy has mandated the central bank to raise interest rate. As a result, interest rate mechanism becomes controversial and not in tandem with other macroeconomic objectives.

Despite a prolific literature on this phenomenon, little attention has been given on how the real interest rate affects the productive capacity of a market-oriented economy like Nigeria. In addition, no strong consensus in the empirical literature on the direct or exact impact of interest rate and how it affects other essential indicators. In addition, previous literature on this phenomenon have largely concentrated on developed countries and other Asian economies with little consideration to the sub-Saharan Africa. Even where such studies are conducted (especially on the Nigerian economy), findings on the impacts of interest rate on sustainable economic growth are at best inconclusive. The inconclusive nature of the previous literature on the relationship between interest rate and economic growth particularly in developing countries has led to a renewed in the debate.

Whether interest rate via the activities of monetary authorities have an impact on economic growth remains an issue of empirical investigation and therefore a relevant research equation for this study. This is possible, given the recent economic recession that bedevilled the Nigerian economy causing a decline in the nation's productive capacity thereby paving ways for monetary authorities to restore stability. Furthermore, the economy witnessed various hurdles which affected the aggregate economic activities in addition to the devastating effects of world oil prices. This scenario has resulted to structural imbalances thereby affecting the country's revenue mobilisation capacity, large and inefficient public sector, inadequate savings and investment capacity as well as persistent large fiscal deficits [1].

In view of that, this study deviates from the previous literature by examining the relationship between interest rate and economic growth through collecting an aggregate index as well as large historical dataset of interest rate over a long period of time. The data trend indicates that interest rate is affected by numerous shocks including the oil price crises and the recent economic recessions of 2017-2018 hence, causing fluctuations and non-linearity in the temporal evolution of the examined variable. Given this, the paper contributed by providing evidence of a long properties of real interest rate over a long period of time while allowing for linear deterministic trends in the model. This also allows in determining the effectiveness of monetary policy intervention when directed to interest rates at different maturities.

The rest of the paper is therefore organised as follows: section 2 deals with the review of empirical literature across developed, emerging and developing economies taking into considerations the various contradictory findings and time frame; section 3 presents the trend of interest rate and further provides a background analysis of interest rate mechanism towards sustainable growth and development; section 4 provides the data source as well as the nature and type of the frequencies; section 5 presents the selected methodologies for model estimation and analysis; section 6 presents the empirical findings and the related discussions in tandem with the previous literature; and finally, section 7 provides summary of findings and highlights some major issues as well as suggest a number of policy recommendations towards sustainable growth in Nigeria.

\section{Review of the Empirical Literature}

Examining the dynamic behaviour of interest rates have become a fascinating area of research given the relevance of the variable in macroeconomic and financial analysis. In the literature, various studies provide assertions on the impact of interest rate on economic growth within developed and developing economies using a different data samples, different techniques of estimation and different time range; but the results remain inconsistent and contradictory. A good number of these literature include the followings: Harvey, Kellard, Madsen and Wohar (2017) used a Vector Autoregression (VAR) model to investigate the historical relation between a new aggregate index of commodity prices, economic activity and interest rate [2]. Evidence shows that commodity prices Granger cause income and interest rates, while interest rates Granger cause commodity prices. By integrating an arbitrage free term structure model of interest rate into a standard $q$ theoretical framework, Lin, Wang, Wang and Yang (2018) examine the impact of the stochastic interest rate and capital liquidity on investment and firm value [3]. Findings established that credit spreads and bond $q$ 
have significant predictive powers on aggregate investment. More so, Gil-Alana, Cunado and Gupta (2017) examine the persistent behaviour of short and long-run real ex-post interest rates based on a long memory approach with nonlinear trend of monthly and annual data in the U.S economy using a fractional order of integration [4]. Findings establish that real interest rates are not persistent and shows a long memory behaviour with a positive and significant coefficients.

By examining the impact of foreign capital inflows on the U.S mortgage interest rate, Ayanou (2016) shows that foreign capital flows are negatively significant and related to the 3year mortgage interest rate [5]. Evidence on the degree of the responsiveness of interest rates to the foreign capital inflows are determined by the type and magnitude of the capital inflows. Nevertheless, Caporale (2015) examines the structural shifts in US interest rates using monthly data covering the period of 1890.01 to 1933.12 based on adopted structural break methodology [6]. Result identifies two structural shifts and implies that U.S entry to World War I caused a major change in the behaviour of nominal interest rates. However, Jermann and Yue (2018) examine the usage of firm interest rate swaps in a model economy driven by aggregate productivity shocks, inflation shocks, and countercyclical idiosyncratic productivity risk [7]. Using a simple equilibrium model to study swap usage, result indicates that interest rate swaps have no essential effect on the real investment behaviour among firms. Akin to that, Maiga (2017) examines the effect of interest rate on economic growth in Nigeria covering the sample period of 1990 to 2013 [8]. Using the OLS regression analysis, results show that interest rate has a significant impact on economic growth in Nigeria for the period under consideration.

According to Dia and Menna (2016), when banks have a lower capital intensity than the industrial sector (like in the U.S), a symmetric productivity shock generates a decline of bank interest margins at impact [9]. Reverse is the case when banks are more capital intensive than the industrial sector, as in the Spain. The authors recommend a real business cycle model where banks concentrate more on traditional role of providing loans to industrial corporations and encounter significant resource costs to provide financial services. More to that, Gopalan and Rajan (2017) examine the impact of foreign bank presence on interest rate pass-through for a panel of 57 emerging and developing economies covering the sample period of 1995 to 2009 [10]. Results indicate that foreign bank presence have a tendency to decrease borrowing rates and improve interest-rate pass-through in countries with relatively high degree of foreign bank presence compared to those with limited presence. On the other hand, foreign banks do not play any significant role in interest rate transmission among low threshold economies.

Furthermore, Pina (2017) examines the relationship between foreign currency international reserve holdings and the global interest rate using a simple and open-economy model in which the central bank manages the international reserves to smooth inflation over time [11]. By employing a quarterly data for 75 countries from 2000 to 2013, result shows a positive relationship between interest rate changes and the reserve transfer as a share of GDP. Correspondingly, Goyal and Arora (2016) analyse the natural interest rate for India by exploiting a few of the relevant structural features of Indian emerging economy [12]. Result indicates that interest rate elasticity of output is generally higher when the natural interest rate is included in aggregate demand estimation. This implies that monetary policy in emerging markets might be expected to have a large impact through policy rates. More so, Soon, Baharumshah and Shariff (2017) examine the stationarity behaviour of ex-post real interest rates for twelve Asian countries and seven advanced industrialised economies [13]. Results support the assertion that real interest rate shows a persistent but mean-reverting behaviour.

In another development, Akhtar, Akhtar, Jahromi and John (2017) measure the impact of interest rate surprises on the Islamic and conventional stock and bond indices using data covering three Islamic and eight non-Islamic countries [14]. Result shows that interest rate surprises have a tendency to establish small impact on the returns and volatility of Islamic than conventional bonds. This is because, Islamic bonds are designed and formulated to avoid explicit interest rate. By implication, it implies that the impact of interest rate is higher on conventional bond and stock due to its acceptable measures and satisfactory criteria on interest rate. In a related scenario, Ammer, Claessens, Tabova and Wroblewski (2018) investigate how the interest rate affects cross-border portfolio investment in the U.S economy [15]. Using data on bond holding for foreign investors from 31 countries covering the period of 2003 to 2016, result shows that lower interest rate (as seen in many developed countries) leads to higher investment, with the impact mostly driven by investment in corporate bonds rather than treasury bonds.

In addition, Lee and Werner (2018) examine the relationship between interest rate and the nominal GDP in U.S, U.K, Germany and Japan [16]. Result shows that causality runs from economic growth to long-term interest rates and that the nominal GDP growth is positive and significantly related with short and long-term rates in all countries under consideration. Besides, Chu, Mathieu and Mbagwu (2018) investigate the relationship between elements of financial statement and the interest rates bank charge on loan [17], and further examine whether the volatility of earnings and the probability of bankruptcy have an impact on banks' use of accounting information in setting the interest rates. Evidence shows the existence of relationship between accounting variables and the bank interest rate, and the impact of accounting variable is stronger when the volatility is low. In the same vein, Aydemir and Ovenc (2016) examine how the level of short-term interest rate and the slope of the yield curve affect bank profitability in an emerging market economy using a dynamic panel model for the period spanning 2002 to 2014 [18]. In the short run, result shows the short-term interest rate and the slope of yield curve with significant negative impact on profits, while in the long-run, the effects is positive and statistically 
significant.

Using a sample of 3385 banks from 47 countries spanning 2005 to 2013, Claessens, Coleman and Donnelly (2018) establish that low interest rates have a significantly greater impact on the bank net interest margin than high interest rate [19]. In addition, the impact is greater on interest income margins than on interest expense margins, and banks with short maturity balance sheets are more affected than those with long maturity balance sheets. Furthermore, Atanasov (2016) examines the relationship between the cross-sections of US stock returns and conditional interest rate risk over the sample period of 1963 to 2014 [20]. By adopting various measures of interest rates and different empirical specifications, the author argues that excess stock returns reflect a premium for conditional upside interest rate risk which is higher than the premium for conditional downside interest rate risk. The conditional upside interest rate risk is significant, while the conditional downside interest rate risk is weak and close to zero.

In a related development, Kurowski and Rogowicz (2017) examine how the negative interest rate policy conducted by central banks contribute to higher market stress [21]. Using an adopted methodology to evaluate key parts of the market, result indicates that risk levels has progressively improved since the introduction of negative interest rate policy in selected economies. Similar to that, Délèze and Korkeamäki (2018) investigate whether new issuers on the European corporate bond markets experience a change in interest rate sensitivity upon the bond issuance [22]. Findings indicate that stock returns have become significantly less sensitive to interest rate fluctuations for firms that enter the publicly traded bond market. Likewise, Sambiri, Otieno, Maurice, Ongiyo and Rombo (2014) investigate the several determinants and factors influencing the lending interest rates and its impacts on the aggregate Kenyan economy [23], and further evaluates the effects of international interest rates on local lending interest rates in determining the impact of budget deficit financing on lending interest rates. Using cointegration test and the ECM technique on time-series data spanning 1980 to 2010, result indicates that the impact of budget deficit and international interest rate has positive and significant impact on the domestic interest rates.

By measuring the channel through which the use of interest rate derivatives affect long growth positively in bank holding companies, Brewer III, Deshmukh and Opiela (2014) support that loan growth is relatively less sensitive to core deposit growth for interest-rate derivatives users compared to non-users [24], and the magnitude of the sensitivity is lower when the extent of derivatives usage is higher. Correspondingly, Were and Wambua (2014) examine the determinants of interest rate spread in Kenya's banking sector based on panel data analysis [25]. Findings indicate that bank-specific factors play a significant role in the determination of interest rate spreads, and these factors influence the interest rate spread positively. Although the impact of monetary policy remains positive but marginally significant. To provide additional evidence on matters related to the banking sub-sector, Mushtaq and Siddiqui (2017) investigate the effects of interest rate on bank deposits among 23 Islamic and 23 non-Islamic countries covering the sample period of 1999 to 2014 [26]. By adopting a panel ARDL model, results show interest rate in Islamic countries with no impact on bank deposits both in the short-run and the longrun period, but indicates a positive and significant impact on bank deposit in non-Islamic countries.

On matters related to interest rate and stock price, Ayopo, Isola and Olukayode (2016) investigate the interactions between macroeconomic variable volatility and stock market return using Exponential General Autoregressive Conditional Heteroskedasticity (EGARCH) technique to analyse monthly data covering the sample period of January 1985 to December 2013 [27]. Finding indicates that stock prices responds significantly to innovations in interest rate and the real GDP in Nigeria. In another related development, Muktadir-al-mukit (2012) analyses the impact of exchange rate and interest rate on the stock market performance in Bangladesh using a monthly data spanning 1997 to 2010 [28]. Using various estimation techniques including the cointegration test, error correction model, analysis of variance decomposition and the Granger causality test, results indicate the existence of long-run relationship among the variables while showing the presence of unidirectional causality from market index to exchange rate and from interest rate to market index. While interest rate depicts a negative impact, exchange rate shows a positive relationship with the market index.

Similarly, Jurkšas (2017) investigates the rationales behind adopting a negative interest rate policy and evaluates how the negative policy rate impact on the various economic sectors [29]. Findings indicate that negative policy rate has significantly affects the numerous economic sectors, but with different magnitude and efficacy. Moreover, negative interest rate establishes a positive effect on aggregate consumption and redistribution of purchasing power from net savers to net borrowers. Additionally, Obamuyi (2009) examines the relationship between interest rates and economic growth in Nigeria covering the sample period of 1970 to 2006 [30]. The author employs the cointegration test and error correction model to measure the short-run and the long-run dynamics relationship among the examined variables. Findings indicate the presence of a long-run relationship and significant impact of interest rate on economic growth in Nigeria. Alike, Onyishi, Arene and Ifiorah (2015) investigate the impact of interest rate reform on agricultural finance and growth in Nigeria [31], and further evaluates the factors that determine the aggregate credit volume to agriculture within the periods of regulation and deregulation and analyse the periodic effects of macroeconomic financial indicators on agriculture's GDP contribution to the Nigerian economy. Using the OLS technique and ARDL model, result shows that interest rate is a strong determinant of aggregate credit volume to the agricultural sector in Nigeria.

More so, Nchor and Darkwah (2015) examine the effect of exchange rate movement and nominal interest rate on the 
Ghanaian inflation rate using time series data spanning 1991 to 2013 [32]. Using the OLS analysis, unrestricted error correction model and the ARDL technique to estimate the collected data, result shows that increased interest rate leads to a raise in macroeconomic indicators including inflation and exchange rate, implying a positive relationship among the variables particularly in the long-run. More to that, Saymeh and Orabi (2013) measure the impact of interest rate, inflation rate, and GDP on real economic growth in Jordan covering the sample period of 2000 to 2010 based on cointegration analysis and Granger causality approach [33]. Results show the existence of a long-run relationship among the variables, and further indicates a significant impact of interest rate on economic growth. Akin to that, Bhunia (2016) examines the relationship between inflation and interest rate with economic growth in India for the period spanning 1992 to 2015 [34]. Using the cointegration test, vector error correction model and Granger causality test, results indicate the existence of long-run causality from economic growth to inflation and interest rates and also a unidirectional causality from economic growth to interest rates.

As observed in the aforementioned literature, the studies provide evidence in favour of positive impact of interest rate. However, another strand of literature in support of negative effect of interest rate on macroeconomic indicators while taking into cognisance the impact on economic growth are equally evaluated. This includes the followings: Salami (2018) investigates the effect of interest rate on the economic growth of Swaziland using time series data covering 1980 to 2016 [35]. Based on the regression analysis, result shows that deposit interest rate and exchange rate have a negative and significant relationship with economic growth. Akin to that, Wuhan and Adnan (2015) examine the impact of interest rate on investment in Jiangsu province of China covering the period of 2003 to 2012 [36]. Using cointegration test and the vector error correction model, result indicates the existence of negative long-run relationship among the variables under consideration. To provide further evidence, Semuel and Nurina (2015) examine the impact of inflation, interest rate and exchange rate on the real GDP in Indonesia spanning 2003 to 2013 [37]. Using the OLS technique, result indicates a significant and negative relationship between interest rate and economic growth. In addition, Ujuju and Etale (2016) examine the relationship between interest rate, economic growth and bank lending in Nigeria using time series data covering 1985 to 2014 [38]. Using OLS technique to analyse the data, results indicate a negative relationship between interest rate and bank lending while positive impact between economic growth and bank lending.

According to Polain, Sterck and Nyssens (2018), saving group practitioners expect interest on loans to discourage borrowing without thoughtful needs or purpose to provide incentives on investment in income generating activities [39]. This implies that, interest rates are provided on loanable funds to discourage irrational borrowing among members. Whereas, Carvalho, Ferrero and Nechio (2016) used a tractable life-cycle model to identify significant features of demographic transition in developed economies from 1990 to 2014 [40]. Results establish a reduction in equilibrium interest rate by one and the half percent. Moreover, Linnemann and Schabert (2015) investigate the role of liquidity premia of asset denominated in a key currency for exchange rate dynamics [41]. By employing a macroeconomic approach to liquidity premia on short-term treasuries emanating from the implementation of monetary policy, result from the panel VAR analysis indicates that changes in interest rate leads to a response in exchange rate that are in relation to uncovered interest rate parity.

By investigating the effect of negative central bank policy rate on bank's propensity to become undercapitalised in a financial crisis, Nucera, Lucas, Schaumburg and Schwaab (2017) find that the risk impact of negative interest rates depends on the business model of a respective banks [42]. Larger banks with more diversified sources of income are seen as less risky compare to smaller or traditional banks. In addition, Holston, Laubach and Williams (2017) apply the Laubach-Williams methodology to measure the natural interest rate in Canada, UK, US and Euro area [43]. In all the four (4) economies, result shows a declining trend of GDP growth and natural interest rate over the past 25 years; demonstrating a considerable amount of co-movement over time. Likewise, Ismailov and Rossi (2017) examine how uncertainty can explain sort-run deviations from Uncertainty Interest Rate Parity (UIRP) in industrialised countries covering Swiss franc, Canadian dollar, British pound, Japanese yen and Euro against the U.S dollar for the period of 1993:M11 to 2015:M1 on exchange rates, three-month Euro LIBOR rates, and the uncertainty measures [44]. Result shows that deviations from UIRP are stronger in period of high uncertainty while UIRP tends to hold in period characterised by low uncertainty.

From 1999 to 2013, Assefa, Esqueda and Mollick (2017) examine the quarterly returns of 21 developed and 19 developing countries [45]. Low economic growth and declining interest rate in developed countries while low output growth with increasing interest rate in developing economies. By adopting a dynamic panels, the authors find a significantly negative effects of interest rate on stock returns in developed economies. Similarly, Kim and Shi (2018) examine the determinants of two (2) key benchmark interest rates in China using quarterly data covering the sample period of 1987 to 2013 [46]. By adopting a constrained ordered probit models, the authors estimate a behavioural equation that models its decision making process for revisions of benchmark deposit rate and lending rate. Result indicates that output gap and the yuan (Chinese monetary unit) appreciation rate tends to play an insignificant roles in determining benchmark interest rate. On the other hand, Rocheteau and Rodriguez-Lopez (2014) develop a tractable model of liquidity provision and the labour market by introducing an explicit market for liquidity into the canonical model of equilibrium unemployment [47], and further analyse the relationship between the fundamental goals of monetary management by providing liquidity and moderating 
the rate of interest towards achieving full employment.

Using a theoretical framework that combines the essence of Ramsay's growth model and the new Keynesian macrodynamics, and further applying the Kalman filter estimation technique, Behera, Pattanaik and Kavediya (2017) examine the natural real interest rate of India covering the period of 2014 to 2015 [48]. Result shows that real interest rate is negative and statistically significant for the period under consideration. Furthermore, Istrefi and Mouabbi (2017) examine whether uncertainty about interest rate is essential for economic activity [49]. The authors investigate the uncertainty effects using a VAR model over a panel of developed countries, and establish that interest rate uncertainty has a persistent and negative effects on the economy. Equally, Duan, Wei and Chen (2014) construct a financial stochastic model for a benchmark interest rate set by a Central Bank [50], and further evaluate the relationship between a macroeconomic indicator and a benchmark interest rate. Using a small data-set on America and China, result for both countries indicate a nonlinear relationship between the benchmark interest rate and the consumer price index.

Furthermore, Kashem and Rahman (2018) investigate the causal relationship among interest rate spread, investor and depositor burden of interest rate spread as well as the interbank borrowing rate in Bangladesh covering the period of 2009 to 2015 [51]. Result shows the existence of bidirectional causality between interest rate spread and interbank borrowing rate. Meaning that, when interest rate spread increases both depositors and investors suffer. By implication, the interbank borrowing rate has a major role to play in the reduction of interest rate spread in Bangladesh. Using a simple model based on the views of John Maynard Keynes that the actions of central bank are the fundamental determinants to explain the behaviour of long-term interest rates in the U.S, Akram and Li (2017) maintain that shortterm interest rates are the most important determinants of long-term interest rates in the U.S [52]. In the long-run, higher government indebtedness has a negative effect on long-run interest rates while it depicts a positive interplay in the short-run period. To provide further evidence, Marins and Vicente (2017) examine the behaviour of market uncertainty about Brazilian interest rates [53], and further adopts an event study method to evaluate the impact of interest rate target decisions on the first two moments of the interest rate risk-neutral distribution. Result shows that distribution of interest rate is significantly altered around the actions of monetary policy for the Brazilian central bank.

Similarly, Broga, Viegas and Jensen (2016) examine the effect of distinct levels of interest rates on the stability of financial network under a modelling framework [54]. The authors establish that bank failure seems to emerge early under sustained high interest rate, and later under sustained high interest rate. Moreover, higher rate of interest have a tendency to result in bankruptcies related to credit losses whereas lack of liquidity under low rate of interest tends to be the primary cause of failures. Also, Kitamura, Muto and
Takei (2016) examine the determinants of loan interest rate pass-through using a bank-level dataset from Japan [55]. Based on the collected data, the authors argue that interest rate pass-through (the responsiveness of loan interest rates to market interest rate variations) tends to be lower for banks with a high proportion of relationship lending. Besides, Karpavicius and $\mathrm{Yu}$ (2017) examine whether corporate financing policies of the US industrial firms have depended on borrowing costs during the last forty years [56]. Using a dynamic partial equilibrium model, results show a weak negative relationship between interest rates and a firm leverage as explained by the relatively high leverage adjustment costs.

In addition, Andries and Billon (2016) evaluate the empirical literature on the retail bank interest rate passthrough in countries within the euro areas [57], and further provide a comprehensive argument on the econometric issues challenging an appropriate assessment of the interest rate pass-through. Findings indicate the existence of the short-run and long-run interest rate pass-through and the adjustment dynamics of bank interest rates. Further result shows an incomplete short-run pass-through and a heterogeneous adjustment of bank interest rates. In another development, Varlik and Berument (2017) investigate the individual effects on economic performance of various monetary policy interest rates for a Turkish central bank covering the period of 2001 to 2016 [58]. By using an extension of Factor-Augmented Vector Autoregressive (FAVAR) models, result shows that interest rate as a policy tool for central bank affects the economic state variables in different variations. The borrowing rate and the lending rate have a weak effect on CPI inflation and capacity utilisation compare to the overnight interest rate, but demonstrate a greater effects on the bank balance sheet.

By utilising a weekly data from January 3, 2003 to March 27, 2015, Huang, Mollick and Nguyen (2016) examine the reactions of U.S stock returns to monetary policy while controlling for oil prices and the value of U.S dollars against major industrialised currencies [59]. Estimation using the VAR technique and the vine copula models identify the structure of dependence across the market and shows that U.S real interest rates have continuously becomes negative over the period. Similarly, Markellos and Psychoyios (2018) examine the US Treasury market volatility and develops new ways of dealing with the underlying interest rate volatility risk over a period of 12 years by adopting innovative approach that is based on a class of model-free interest rate volatility [60]. Result shows a negative interest rate volatility risk premium, which is priced in the market and significantly related to equity volatility risk.

Using a structuralist model, Sonaglio, Campos and Braga (2016) investigate the effects of changes in the monetary (interest rate) and exchange rate policy as well as the composition of total exports on the Brazilian aggregate output growth [61]. Result shows that interest have a negative impact and while exchange rate reveals a positive and significant relationship. Moreover, Barrell, Karim and 
Ventouri (2017) examine the impact of interest rate liberalisation on OECD banking crises, controlling for the standard macro prudential indicators that exist in the present literature covering the sample period of 1980 to 2012 [62]. The authors further test the direct effect of interest rate liberalisation on crisis probabilities and its indirect impacts through capital adequacy. Result shows that interest rate liberalisation has a crises reducing effect, and it appears that the beneficial effects work by strengthening capital buffers. Also, Turner and Spinelli (2011) examine the interest rate growth differentials among a panel of 23 OECD countries [63]. Results show that decrease in interest rate is partly explained by the low inflation volatility associated with the adoption of monetary policy regimes that aim for a low inflation rate.

Similarly, Chughtai, Malik and Aftab (2015) analyse the effects of major economic variables comprising of inflation rate, interest rate and exchange rate on economic growth of Pakistan covering the sample period of 1981 to 2013 on time series data [64]. Using the linear regression model, results show that interest rate and inflation establish negative impact while exchange rate shows a positive relationship with the economic growth. In addition, Udoka and Anyingang (2012) examine the effect of interest rate fluctuation on the economic growth of Nigeria using time series data covering 1970 to 2010 [65], and further assess the interest rate deregulation regime. Using the OLS technique, result indicates the presence of negative association and interplay between interest rate and economic growth in Nigeria. This implies that, increase in interest rate leads to a down slope in economic growth thereby hindering the growth potentials of the country.

Moreover, Oteng, David and Emmanuel (2016) investigate the effects of exchange rate, inflation and interest rate on the real GDP in Ghana covering the sample period of 1975 to 2015 on quarterly data [66]. Using a cointegration analysis based on the framework of VAR model, the result shows the existence of long-run relationship between the examined variables. Further evidence indicates that interest rate exerts a negative effect on the economic growth, while the Granger Causality test shows unidirectional causality running from inflation rate and interest rate to real GDP. To buttress this argument, Raymond (2014) measures the impact of changes in interest rate on inflation in Nigeria using bivariate and multiple regression technique based on time series data covering the sample period of 1980 to 2010 [67]. Result shows that changes in interest rates and increased money supply are related with the increase in inflationary pressures in Nigeria. In a similar development, Babalola, Danladi, Akomolafe and Ajiboye (2015) examine the impacts of inflation and interest rate in Nigeria using time series data covering 1981 to 2014 [68]. By adopting the OLS technique, granger causality and the cointegration analysis, findings indicate that interest rate and inflation exert negative impacts on the economic growth; although no causality exists between interest rate and inflation with economic growth for the period under consideration.

Likewise, Lunsford (2017) examines the long-run relationship between real interest rates and productivity growth spanning 1914 to 2016 covering the entire history of the Federal Reserve System [69]. By using a total factor productivity to measure the total output, results show the existence of a negative relationship between interest rate and the productivity growth. From the South African economy, Jordaan (2013) examines the impact of interest rate changes from a macroeconomic perspective on South African households by adopting a macroeconomic model and a social accounting matrix [70]. Result from the macroeconomic model indicates the presence of negative effect of interest rate on economic growth. Further result from the impact analysis shows that increase in interest rate establishes a highly negative impact on the high-income earners compare to the low-income group. Correspondently, di Giovanni and Shambaugh (2008) examine the relationship between interest rates and annual real output growth in major industrial countries using a panel estimation approach [71]. Findings reveal that interest rates have a contractionary impact on the real output growth within the domestic economy most particularly for countries with fixed exchange rate regime.

In another development, Bosworth (2014) examines the long-run determinants of interest rates and evaluates the relationship between variations in interest rates and the rate of economic growth [72]. Using data from a number of large economies are employed to demonstrate the influence of foreign interest rates in an increasingly globalised world capital market. A method is developed to adjust both long and short-run interest rates for expected inflation. Results show a weak relationship between interest rate and economic growth. Furthermore, Hansen and Seshadri (2013) examine the real interest rates and productivity growth in U.S with the aim of estimating its long-run relationship using annual series covering the period of 1901 to 2011 [73]. Result shows a negative relationship between interest rate and productivity growth, implying that real interest rate is mildly countercyclical.

On a contrary perspectives, Araujo (2017) investigates the relationship between real GDP growth and selected macroeconomic indicators including the interest rate using a regression approach [74]. Based on time series approach, findings reveal no significant relationship between interest rate and GDP growth. In addition to that, Faroh and Shen (2015) investigate the effects of interest rate and foreign direct investment on the economic growth of Sierra Leone using a time series data spanning 1985 to 2012 [75]. Based on multiple regression analysis, result shows that interest rate is an insignificant element causing the variability of foreign direct investment, meaning that, interest rate has no effect on the foreign direct investment.

Given this background and the various strands of literature on the effects of interest rate on macroeconomic indicators most particularly the output growth, this present study carefully examine the impact of real interest rate on the economic growth of Nigeria using recent and up-to-date index from the archive of the Central Bank of Nigeria. 


\section{Management of Interest Rate in Nigeria}

The relationship between interest rate and economic growth is derived from the use of interest rate as an instrument for maintaining stability through regulating undesirable elements like inflation and high consumption rate. More so, interest rate has played a significant role among other instruments used by the public authorities in coordinating the activities of monetary policy in Nigeria. For more than two decades, interest rate has been fluctuating thereby affecting other indicators (see Figure 1). This fluctuating movement indicates that factors other than the monetary policy measures are equally responsible. At a given point, a preferential interest rate is adopted and designed based on the fact that market would disregard certain essential sectors, when freely applied. As a result, interest rates are adjusted through the market forces with the aim of encouraging the investment level in numerous essential sectors of the economy. Noticeable among the essential sectors include the agriculture, solid minerals and the manufacturing sector which are accorded high priority, while all commercial banks are also given directives to charge preferential interest rate on loans toward encouraging rapid industrialisation through small-scale enterprises [65].

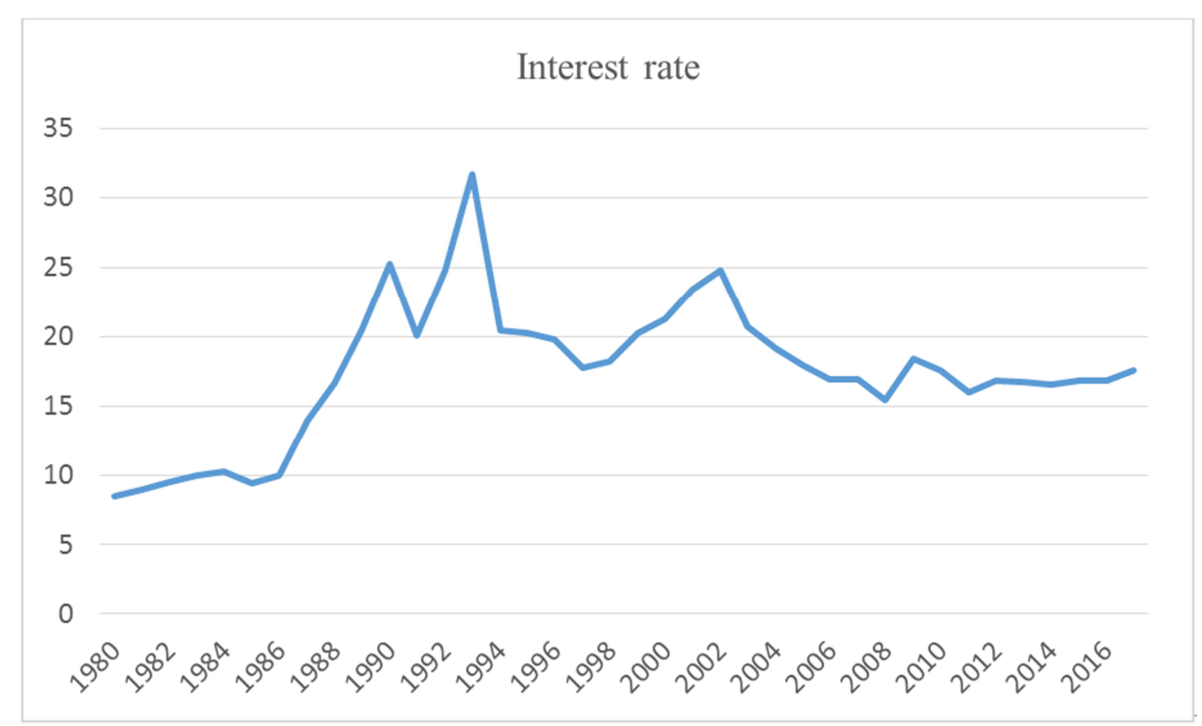

Figure 1. Trend of interest in Nigeria, 1980-2017.

In an attempt to maintained stability, the response of the public authorities in Nigeria has always been the introduction of policy reform measures. In 1986, the government introduced a policy programme called the Structural Adjustment Programme (SAP) with the aim of setting the economy on the path of sustainable growth and development. As a result, several reform measures are introduced including the financial sector liberalisation policies. By the same year in 1986 , interest rate was slated as $2.5 \%$ but later increased to $8.9 \%$ [76]. Consequently, markets for auctioning some government securities were introduced, an upward review of capital adequacy standards were in place and a ban on the extension of credit based on foreign exchange deposits were enforced.

Since the year 1987, Nigeria has been adopting an interest rate measure that is market-determine and which do not allow for direct intervention in the operational workings of the economy. Years after; specifically in 1994, there is another policy change and the government introduced a number of measures aimed at regulating the interest rate. This policy change led to a comprehensive disparity and unreasonably high interest rate thereby distorting the market and the aggregate economy. Consequently, deposit rate are once more pecked at $12 \%$ per annum while a ceiling of $21 \%$ was fixed for lending purposes. The vacuum created by the 1994 interest rate reforms are further retained up to 1995 with slight adjustment to allow for flexibility.

In an attempt to deregulate the interest rate in 1996, banks are at the liberty to determine the interest rate structure in consultation with its valued clients. On the other hand, the central bank retained the unrestricted power to interfere in the money market with the view to ensuring orderly growth in the interest rate mechanism. The policy deregulation was retained in 1997 and as a results, recorded a relative stability. However, the market-based approach for the interest rate management has always been related with significant volatility in Nigeria. This volatility has prompted the central bank to ensure more regulations and supervise the interest rate administration. The apex bank introduced an indirect monetary instruments with the view to controlling the interest rate and inflation mechanism towards accelerating economic growth.

In the year 2000, monetary policy measures in addition to other financial sector reforms was formulated with the aim of maintaining external and internal balances. In particular, the policy framework was designed to ensure and maintain a single digit inflation rate. To achieve this aim, the monetary measures are directed towards limiting excess liquidity in the 
banking sector and further encouraging the sustainability of external and the stability of financial system. Subsequently, the monetary policy committee in 2007 review the operations of key macroeconomic indicators, implementation of monetary and fiscal policies as well as other matters arising. Even with the glaring presence of economic challenges, the committee noted with great satisfaction the overall macroeconomic performance in the country.

\section{Data Source}

The study uses annual time series data for interest rates and real GDP covering the sample period of 1980 to 2017 from the archive of Central Bank of Nigeria and the national account data of World Bank. The period is chosen based on the availability of data frequencies and covers major economic and political transitions in Nigeria. These sources of data provide record for various kinds of economic, financial and demographic data for the Nigerian economy. The obtained data frequencies are tested and analysed in order to provide a valid conclusions on the impact of interest rate on economic growth in Nigeria.

\section{Methodology}

Many of the available literature that evaluate the impact of interest rate on economic growth did so using the OLS regression techniques. However, direction of causality among the variables cannot be attained from an estimated regression coefficients. In other words, regression coefficients do not provide information about the impact spread or innovations over time. A VAR framework is well-suited for this purpose. Instead of making assumptions about the contemporaneous causality relations between the variables, the empirical measure of exogenous innovations in both variables can be used to estimate the Impulse Response Function (IRF) and its corresponding Variance Decomposition (VD).

In a VAR model, both interest rate and real GDP (proxy for economic growth) are specified as endogenous variables. A variable is said to be endogenous if any other variable (s) explain a larger percentage of its variations over a forecast horizon. On the other hand, a variable is called exogenous if any other variable (s) do not explain its variations over a forecasting time period. In addition to measuring the relationship between the variables, the VAR model allows to estimate IRF for the interest rate. These generalised IRFs provide the time-path for short-run dynamic interplay that arises from a shock to the variables in the system. Afterwards, its corresponding VD are estimated. The forecast VD provides the forecast error variance explained by innovations (fluctuations) in each variable.

In a simpler format, the model is formulated as:

$$
\mathrm{GDP}=\mathrm{f}(\mathrm{INT})
$$

To express the model using econometrics formulation, eq. (1) is further stated from a functional form to an algebraic expression as follow:

$$
\mathrm{GDP}_{\mathrm{t}}=\beta_{0}+\beta_{\mathrm{t}}+\beta_{1} \mathrm{INT}+\mathrm{t}
$$

Where, GDP $=$ economic growth at time $\mathrm{t} ; \beta_{0}=$ intercept or constant term; $\beta_{\mathrm{t}}=$ parameter that captures the linear trend in the model; INT $=$ interest rate; $t=$ error term with the assumption of zero mean and constant variance.

By taking the logarithm of the variables as stated in equation (2), it results to:

$$
\operatorname{LGDP}_{\mathrm{t}}=\beta_{0}+\beta_{\mathrm{t}}+\beta_{1} \operatorname{LINT}+\mathrm{t}
$$

The rationale for transforming the variables into natural $\log$ is to ensure proper scaling among the model parameters and to further obtain their elasticity coefficient.

The VAR representation of the variables are specified as follows:

$$
\mathrm{Y}_{\mathrm{t}}=+\delta_{\mathrm{t}} \mathrm{Y}_{\mathrm{t}-1}+\ldots \delta_{\mathrm{p}} \mathrm{Y}_{\mathrm{t}-\mathrm{p}}+\mathrm{V}_{\mathrm{t}}
$$

Where, $Y_{t}$ is a $\left(\mathrm{K}^{*} 1\right)$ vector of endogenous variables; is a vector of intercept; $\delta_{p}$ are the fixed VAR coefficients matrices; $v_{t}=\left(v_{l t} \ldots v_{k t}\right)$ is an unobserved error term; and $\mathrm{K}$ is the number of variables in the model. However, the VAR lag lengths are selected based on the Akaike Information Criterion (AIC) and Schwarz Criterion (SC).

In addition to the VAR model, a Granger causality test is adopted to measure the variable' relationship. The test uses twin factors of VAR approach to establish a causal relationship between the concerned variables. A variable " $A$ " Granger-causes variable " $B$ " if the past changes of " $A$ " could assist to predict a current changes of " $\mathrm{B}$ ". The causal relationship is called unidirectional causality when variable " $A$ " Granger-causes " $B$ " and not vice versa. Moreover, when variable "A" Granger-causes "B"; and variable "B" also Granger-causes " $\mathrm{A}$ ", the condition is refers to as bidirectional causality. The rationale for chosen the Granger causality among other techniques is due to its superiority and favourable response to both small and large sample observations. The model is specified as follows:

$$
\begin{aligned}
\Delta Y_{t} & =\delta_{0}+\sum_{i=1}^{p} \beta 1 i \Delta Y_{t-i}+\sum_{i=0}^{p} \emptyset 1 i \Delta X_{t-i}+v_{t} \\
\Delta X_{t} & =\delta_{0}+\sum_{i=1}^{p} \beta 2 i \Delta X_{t-i}+\sum_{i=0}^{p} \varnothing 2 i \Delta Y_{t-i}+U_{t}
\end{aligned}
$$

If $X_{t}$ Granger causes $Y_{t}$, then the current values of $Y_{t}$ are determined by the past values of $X_{t-1}$. The test of null hypothesis $H_{o}: \delta_{\mathrm{t}}=0$ can be conducted with the F-test.

\section{Results and Discussion}

In this section, the estimated findings are present and analysed in relation to the study objective. Before the estimation, unit root test is conducted on the model coefficient to determine the level of stationarity and further avoid spurious estimation.

\subsection{Unit Root Test}

Since the study utilises a time series observations which are frequently nonstationary and lead to spurious estimates, 
the use of a unit root test is therefore necessary. The most common unit root test available in the previous literature is the Augmented Dickey-Fuller (ADF) test. The ADF test is a parametric measure initially developed by Dickey and Fuller in 1979 and later in 1981. Unfortunately, using Monte Carlo simulations; it has been established and confirmed that the power of the ADF test is marginally small. In other words, the ADF test does not have the potentials to noticeably differentiate between nonstationary and stationary series with a high degree of autocorrelation and is sensitive to structural breaks. In order to avoid these deficiencies, a semiparametric approach known as Philips-Perron (PP) test is adopted. The PP test gives robust estimates when the series has evidence of serial correlation and heteroskedasticity. Results for these tests are presented in Table 1 as follows:

Table 1. Result of the unit root test.

\begin{tabular}{llll}
\hline Variables & Level & 1st difference & Decision \\
\hline Augmented Dickey-Fuller test & & \\
GDP & 0.1582 & $0.0510^{* *}$ & I (1) \\
INT & 0.6313 & $0.0027^{*}$ & I (1) \\
Philips-Perron test & & & \\
GDP & 0.5332 & $0.0457^{*}$ & I (1) \\
INT & 0.6240 & $0.0001^{*}$ & I (1) \\
\hline
\end{tabular}

Note: $* * *$ indicate stationary at $5 \%$ and $10 \%$ significance level respectively.

Result from Table 1 shows the outcome of unit root test based on ADF and PP approaches, respectively. It is obvious that data of these kind are not stationary at level. This fact is quite natural for all economic and financial variables including the interest rate. Conversely, application of first differentiation to the data index result to the stationary state. In other words, both ADF and PP tests indicate stationary

Response to Cholesky One S.D. after first differentiation at $10 \%$ and $5 \%$ levels. Meaning that, the t-statistics are greater than its corresponding critical values both in ADF and the PP tests, respectively.

\subsection{VAR Estimates and Lag Order Selection}

As indicated by $\mathrm{AIC}$ and SC information criteria, the optimal lag lengths for the VAR estimation is 2. At this chosen lag, the residuals are not serially correlated and are found to be homoskedastic. Meaning that, results are valid and reliable for inference. In order to use the VAR model to analyse the interactions between the model variables, it is necessary to identify its impulse response functions by recovering structural innovations from the estimated residuals coming from the VAR model. In other words, since the coefficients of a VAR model are to a certain extent difficult to explain, analysis of the impact relationship are conducted using the IRF and its corresponding VD approaches.

\subsubsection{Impulse Response}

The dynamic responses between the interest rate and the real GDP are measured using the IRF analysis which traces the response of a variable to one-standard deviation change in any other variable of the model. Moreover, the IRF traces out the response of current and future values of each of the variables to one-standard-deviation shock in the current value of one of the VAR errors, assuming that this error returns to zero in subsequent periods and that all other errors are equal to zero. In this study, the IRF is employed to measure the pattern of dynamic impulse responses of interest rates to shocks in real GDP. Hence, estimated findings are presented in Figure 2 as follows:

(d.f. adjusted) Innovations \pm 2 S.E.

Response of LGDP to LGDP

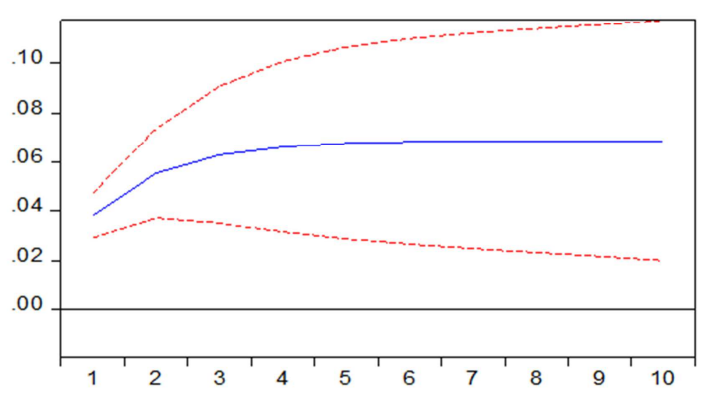

Response of LINT to LGDP

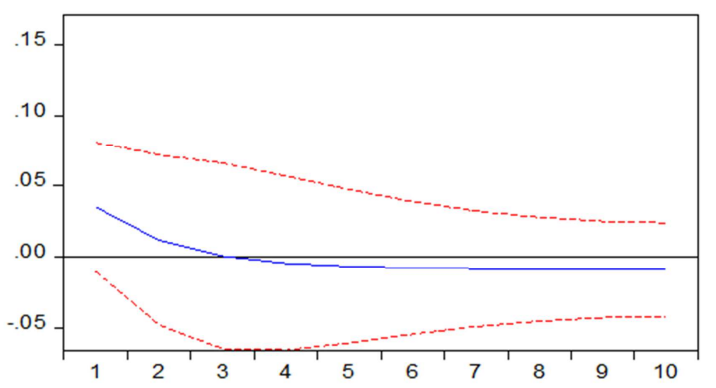

Response of LGDP to LINT

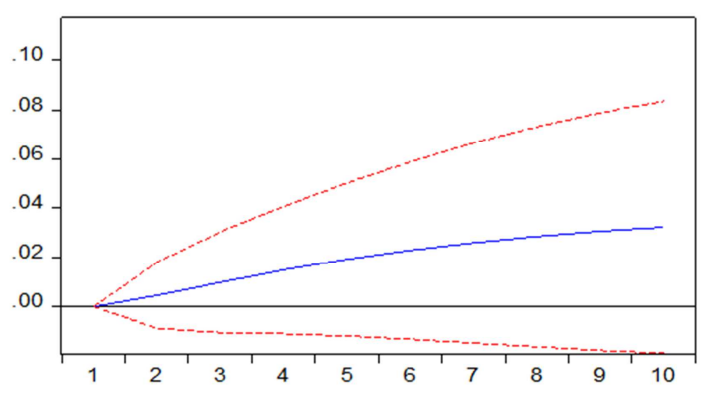

Response of LINT to LINT



Figure 2. Response of interest rate on the real GDP. 
Result in Figure 2 shows the response of interest rate on the real GDP and vice-versa. For the 10-year period on the response of real GDP to interest rate, findings indicate that one-standard deviation shock in real GDP leads to a corresponding increase in interest rate by $1 \%(0.010)$ in the third month. This positive trend continues up to the tenth period where it recorded an increase of $3.2 \%$. This implies that, real GDP has a positive impact on interest rate both at the short-run and the long-run period.

On the other hand, the response of interest rate to the real GDP given a one-standard deviation shock in interest rate shows a positive impact of $0.1 \%$ in the short-run period but maintained a downward slope till the tenth year period. Despite a successive slight depreciation in the medium term, the overall impact over a period shows a decline trend of interest rate throughout the horizon. By implications, the response of interest rate on the real GDP is positive in the short-run but negative at the medium and long-run periods. The basis of this analysis is largely concentrated on the longrun impact, and therefore established that interest rate has a negative effect on the real GDP for the period under consideration. Similar result is found by Babalola et al. (2015); Ujuju and Etale (2016); Assefa et al. (2017); that interest rate has a negative and significant impacts on economic growth $[68,38,45]$. Factors that are responsible for this development includes inappropriate implementation of monetary policies that create an enabling environment for increased investment and trade liberalisation policies thereby affecting other essential indicators and further establishing a retarding impact on economic growth.

\subsubsection{Variance Decomposition}

Other measures for evaluating the dynamic behaviour of variables in a statistical mode is through the VD approach. This approach breaks the variance of the forecast error for each variable into components that can be attributed to each of the endogenous variable (s). Moreover, a VD of a particular variable shows a proportionate change of that variable due to its own changes; and changes to other variable (s) of the same model over a time period. While the IRF traces the effects of a shock to one endogenous variable on to the other variables in the VAR system, the VD separates the variation in an endogenous variable into the component shocks to the VAR.

The forecast VD provides the forecast error variance explained by variations in the variables. Consequently, the
VD provides information about the relative importance of each random innovation in affecting the variables in the VAR model. The forecast error variance decomposition is the percentage of variance of the error made in forecasting a variable due to a specific shock at a given horizon. For this study, a VD for interest rate is evaluated and the results are presented as follows:

Table 2. Variance decomposition of interest rate.

\begin{tabular}{llll}
\hline \multicolumn{4}{l}{ Variance Decomposition of LINT: } \\
\hline Period & S.E. & LGDP & LINT \\
\hline 1 & 0.139115 & 6.408063 & 93.59194 \\
2 & 0.181671 & 4.193347 & 95.80665 \\
3 & 0.205610 & 3.275428 & 96.72457 \\
4 & 0.220276 & 2.889833 & 97.11017 \\
5 & 0.229546 & 2.741322 & 97.25868 \\
6 & 0.235487 & 2.709345 & 97.29066 \\
7 & 0.239319 & 2.740342 & 97.25966 \\
8 & 0.241801 & 2.808217 & 97.19178 \\
9 & 0.243414 & 2.899045 & 97.10096 \\
10 & 0.244469 & 3.004761 & 96.99524 \\
Cholesky Ordering:LGDPLINT & & \\
\hline
\end{tabular}

Table 2 shows the result of variance decomposition of interest rate over a tenth-year horizon. It can be seen that, when real GDP is decreasing; interest rate is increasing, thus implying an inverse relationship between the variables. As the real GDP decreases from 6 percent in the initial period to 3 percent in third period, interest rate accelerates from 93 percent to 96 percent. More so, in the short-run (period 1 to 3 ), changes in interest rate account for over 90 percent variation with a positive and increasing trend. In the long-run period, it shows about 97 percent at the eighth and ninth horizons but later improves to 96 percent at the tenth horizon. Meaning that, interest rate has a significant and negative relationship with real GDP for the period under consideration. This result is consistent with the literature as submitted by Babalola et al. (2015); Ujuju and Etale (2016) [68, 38]. In addition, the result is also in conformity with the outcomes of IRF as earlier evaluated (see Figure 2).

\subsection{Granger Causality Result}

In order to measure the possible causations between the examined variables, a Granger causality is employed for that purpose. The null hypothesis of this model is that variable " $\mathrm{A}$ " does not Granger cause variable " $\mathrm{B}$ " and it is further evaluated using the F-statistic. Results using nine lags in the model specification is given as follows:

Table 3. Pairwise Granger causality test.

\begin{tabular}{llll}
\hline Null hypothesis & F-statistic & P-values & Decision \\
\hline Interest rate does not Granger cause real GDP & 3.03564 & 0.0493 & Reject null hypothesis \\
Real GDP does not Granger cause interest rate & 4.93953 & 0.0100 & Reject null hypothesis \\
\hline
\end{tabular}

Table 3 shows the result of pairwise Granger causality test based on two variables - interest rate and real GDP. Findings indicate that the null hypothesis which states that interest rate does not Granger cause real GDP is rejected at 5 percent level of significance. In addition, the real
GDP also Granger cause interest rate at 5 percent significance level. This implies that, interest rate Granger cause real GDP and the real GDP also Granger cause interest rate thereby indicating a bi-directional causality between the variables. By implications, both interest rate 
and real GDP have significant impact on each other over the time period.

\section{Conclusion and Policy Implications}

This study evaluates the impact of interest rate on the economic growth of Nigeria using annual time series data spanning 1980 to 2017 . This phenomenon is particularly interesting from a theoretical standpoint as well as for the understanding of financial market mechanisms. The VAR model and the Granger causality test are employed to estimate the model coefficients and measure the causal relationship among the concerned variables. From the IRF and its corresponding VD estimates, result shows the existence of negative relationship between interest rate and economic growth in Nigeria. Furthermore, the Granger causality test indicates the presence of bi-directional causal relationship among the model coefficients. It is a fact that interest rate plays a vital role in the macroeconomic management of Nigeria. As such, persistent fluctuations in the variable could reduce the investors' confidence due to high uncertainties on the investment returns thereby establishing a negative impact on the economy. Consequently, monetary authorities should designed and implement interest rate policies that enhance investment and take into cognisance other elements that retard investment progression. To attain the desired growth level in Nigeria, monetary authorities and policy makers should adopt policy measures that are growth oriented and have the potentials to accelerate the economy to higher productivity and sustainable economic growth.

\section{References}

[1] Idris, M., \& Bakar, R. (2017). Public sector spending and economic growth in Nigeria: In search of a stable relationship. Asian Research Journal of Arts \& Social Sciences, 3 (2), 1-19.

[2] Harvey, D. I., Kellard, N. M., Madsen, J. B., \& Wohar, M. E. (2017). Long-run commodity prices, economic growth and interest rate: $17^{\text {th }}$ century to the present day. World Development, 89, 57-70.

[3] Lin, X., Wang, C., Wang, N., Yang, J. (2018). Investment, Tobin's q, and interest rates. Journal of Financial Economics. ARTICLE IN PRESS.

[4] Gil-Alana, L. A., Cunado, J., \& Gupta, R. (2017). Evidence of persistence in U. S short and long- term interest rates. Journal of Policy Modelling, 39, 775-789.

[5] Ayanou, T. (2016). Foreign capital inflows to the USA and mortgage interest rates. Journal of Housing Economics, 34, 114.

[6] Caporale, T. (2015). Regime changes and interest rate risk. Economic letters, 136, 204-206.

[7] Jermann, U. J., \& Yue, V. Z. (2018). Interest rate swaps and corporate default. Journal of Economic Dynamics and Control, 88, 104-120.
[8] Maiga, F. K. (2017). Impact of interest rate on economic growth in Nigeria. Pyrex Journal of Business and Finance Management Research, 3 (3), 98-111.

[9] Dia, E., \& Menna, L. (2016). Productivity shocks, capital intensities and bank interest rates. Journal of Macroeconomics, 48, 155-171.

[10] Gopalan, S., \& Rajan, R. S. (2017). Does foreign bank presence affect interest rate pass-through in emerging and developing economies? Journal of Macroeconomics, 54, 373392.

[11] Pina, G. (2017). International reserves and global interest rates. Journal of International Money and Finance, 74, 371-385.

[12] Goyal, A., \& Arora, A. (2016). Estimating the Indian natural interest rate: A semi-structural approach. Economic Modelling, $58,141-153$.

[13] Soon, S., Baharumshah, A. Z., \& Shariff, N. S. M. (2017). The persistence in real interest rates: Does it solve the intertemporal consumption behaviour puzzle. Journal of International Financial Markets, Institutions \& Money, 50, $36-51$.

[14] Akhtar, S., Akhtar, F., Jahromi, M., \& John, K. (2017). Impact of interest rate surprises on Islamic and conventional stocks and bonds. Journal of International Money and Finance, 79, 218-231.

[15] Ammer, J., Claessens, S., Tabova, A., \& Wroblewski, C. (2018). Home country interest rates and international investment in U. S. bonds. Journal of International Money and Finance, ARTICLE IN PRESS.

[16] Lee, K., \& Werner, R. A. (2018). Reconsidering monetary policy: an empirical examination of the relationship between interest rates and nominal GDP Growth in the U. S., U. K., Germany and Japan. Ecological Economics, 146, 26-34.

[17] Chu, L., Mathieu, R., \& Mbagwu, C. (2018). The association between firm fundamentals and bank interest rates under different measures of risk. Advances in Accounting, 41, 46-58.

[18] Aydemir, R., \& Ovenc, G. (2016). Interest rates, the yield curve and bank profitability in an emerging market economy. Economic Systems, 40, 670-682.

[19] Claessens, S., Coleman, N., \& Donnelly, M. (2018). "LowFor-Long" interest rates and banks' interest margins and profitability: Cross-country evidence. J. Finan. Intermediation, $35,1-16$.

[20] Atanasov, V. (2016). Conditional interest rate risk and the cross-section of excess stock returns. Review of Financial Economics, 30, 23-32.

[21] Kurowski, L. K., \& Rogowicz, K. (2017). Negative interest rates as systemic risk event. Finance Research Letters, 22, 153-157.

[22] Délèze, F., \& Korkeamäki, T. (2018). Interest rate risk management with debt issues: Evidence from Europe. Journal of Financial Stability, 36, 1-11.

[23] Sambiri, M. J., Otieno, O. D., Maurice, M., Ongiyo, C. O., \& Rombo, K. (2014). Lending rates and its impact on economic growth in Kenya. Journal of Economics and Sustainable Development, 5 (19), 89-97. 
[24] Brewer III, E., Deshmukh, S., \& Opiela, T. P. (2014). Interestrate uncertainty, derivatives usage, and loan growth in bank holding companies. Journal of Financial Stability, 15, 230240 .

[25] Were, M., \& Wambua, J. (2014). What factors drive interest rate spread of commercial banks? Empirical evidence from Kenya. Review of Development Finance, 4, 73-82.

[26] Mushtaq, S., \& Siddiqui, D. A. (2017). Effect of interest rate on bank deposits: Evidences from Islamic and non-Islamic economies. Future Business Journal, 3, 1-8.

[27] Ayopo, B. A., Isola, L. A., \& Olukayode, S. R. (2016). Stock market response to economic growth and interest rate volatility: Evidence from Nigeria. International Journal of Economics and Financial Issues, 6 (1), 354-360.

[28] Muktadir-al-mukit, D. (2012). Effects of interest rate and exchange rate on volatility of market index at Dhaka stock exchange. Journal of Business and Technology, VII (2), 1-18.

[29] Jurkšas, L. (2017). An impact assessment of negative interest rates of central banks. EKONOMIKA, 96 (1), 25-46.

[30] Obamuyi, T. M. (2009). An investigation of the relationship between interest rates and economic growth in Nigeria, 19702006. Journal of Economics and International Finance, 1 (4), 093-098.

[31] Onyishi, L. O., Arene, C. J., \& Ifiorah, C. M. (2015). Impact of interest rate reform on agricultural finance and growth in Nigeria. RJOAS, 1 (37), 29-37.

[32] Nchor, D., \& Darkwah, S. A. (2015). Inflation, exchange rates and interest rates in Ghana: an autoregressive distributed lag model. Acta Universitatis Agriculturae et Silviculturae Mendelianae Brunensis, 63 (3), 969-977.

[33] Saymeh, A. F., \& Orabi, M. M. A. (2013). The effect of interest rate, inflation rate, GDP, on real economic growth rate in Jordan Asian Economic and Financial Review, 3 (3), 341-354.

[34] Bhunia, A. (2016). How inflation and interest rates are related to economic growth? A case of India. Journal of Finance and Accounting, 4 (1), 20-26.

[35] Salami, F. K. (2018). Effect of interest rate on economic growth: Swaziland as a case study. Journal of Business and Financial Affairs, 7 (3), 1-5.

[36] Wuhan, L., \& Adnan, K. (2015). The effect of interest rate on investment: Empirical evidence of Jiangsu Province, China. Journal of International Studies, 8 (1), 81-90.

[37] Semuel, H., \& Nurina, S. (2015). Analysis of the effect of inflation, interest rates, and exchange rates on Gross Domestic Product (GDP) in Indonesia. Proceedings of the International Conference on Global Business, Economics, Finance and Social Sciences (GB15 Thai Conference) ISBN: 978-1941505-22-9 Bangkok, Thailand, 20-22 February 2015 Paper ID: T507.

[38] Ujuju, L. E., \& Etale, L. M. (2016). Macroeconomic analysis of the relationship between interest rate, economic growth and bank lending in Nigeria. European Journal of Business and Innovation Research, 4 (3), 29-37.

[39] Polain, M. L., Sterck, O., \& Nyssens, M. (2018). Interest rates in saving groups: Thrift or threat. World Development, 101, 162-172.
[40] Carvalho, C., Ferrero, A., \& Nechio, F. (2016). Demographics and real interest rates: Inspecting the mechanism. European Economic Review, 88, 208-226.

[41] Linnemann, L., \& Schabert, A. (2015). Liquidity premia and interest arte parity. Journal of International Economics, 97, 178-192.

[42] Nucera, F., Lucas, A., Schaumburg, J., \& Schwaab, B. (2017). Do negative interest rates make banks less safe? Economics Letters, 159, 112-115.

[43] Holston, K., Laubach, T., \& Williams, J. C. (2017). Measuring the natural rate of interest: international trends and determinants. Journal of International Economics, 108, 559-575.

[44] Ismailov, A., \& Rossi, B. (2017). Uncertainty and deviations from uncovered interest rate parity. Journal of International Money and Finance. ARTICLE IN PRESS.

[45] Assefa, T. A., Esqueda, O. A., \& Mollick, A. V. (2017). Stock returns and interest rate around the world: A panel data approach. Journal of Economics and Business, 89, 20-35.

[46] Kim, H., \& Shi, W. (2018). The determinants of the benchmark interest rate in China. Journal of Policy Modelling, 40, 395-417.

[47] Rocheteau, G., \& Rodriguez-Lopez, A. (2014). Liquidity provision, interest rates, and unemployment. Journal of Monetary Economics, 65, 80-101.

[48] Behera, H. K., Pattanaik, S., \& Kavediya, R. (2017). Natural interest rate: Assessing the stance of India's monetary policy under uncertainty. Journal of Policy Modelling, 39, 482-498.

[49] Istrefi, K., \& Mouabbi, S. (2017). Subjective interest rate uncertainty and the macroeconomy: A cross-country analysis. Journal of International Money and Finance, ARTICLE IN PRESS.

[50] Duan, Q., Wei, Y., \& Chen, Z. (2014). Relationship between the benchmark interest rate and a macroeconomic indicator. Economic Modelling, 38, 220-226.

[51] Kashem, M. A., \& Rahman, M. M. (2018). Nexus between the banking sector interest rate spread and interbank borrowing rate: An econometric investigation for Bangladesh. Research in International Business and Finance, 43, 34-47.

[52] Akram, T., \& Li, H. (2017). What keeps long-term U. S interest rates so low? Economic Modelling, 60, 380-390.

[53] Marins, J. T. M., \& Vicente, J. V. M. (2017). Do the central bank actions reduce interest rate volatility? Economic Modelling, 65, 129-137.

[54] Broga, K. M., Viegas, E., \& Jensen, H. J. (2016). Model analysis of the link between interest rates and crashes. Physica A, 457, 225-238.

[55] Kitamura, T., Muto, I., \& Takei, I. (2016). Loan interest rate passthrough and changes after the financial crisis: Japan's evidence. Journal of Japanese and International Economies, 42, 10-30.

[56] Karpavicius, S., \& Yu, F. (2017). The impact of interest rates on firms' financing policies. Journal of Corporate Finance, 45, 262-293.

[57] Andries, N., \& Billon, S. (2016). Retail bank interest rate pass-through in the euro area: An empirical survey. Economic System, 40, 170-194. 
[58] Varlik, S., \& Berument, M. H. (2017). Multiple policy interest rates and economic performance in a multiple monetarypolicy-tool environment. International Review of Economics and Finance, 52, 107-126.

[59] Huang, W., Mollick, A. V., \& Nguyen, K. H. (2016). U. S. stock markets and the role of real interest rates. The Quarterly Review of Economics and Finance, 59, 231-242.

[60] Markellos, R. N., \& Psychoyios, D. (2018). Interest rate volatility and risk management: Evidence from $\mathrm{CBOE}$ Treasury options. The Quarterly Review of Economics and Finance, 68, 190-202.

[61] Sonaglio, C. M., Campos, A. C., \& Braga, M. J. (2016). Effects of interest and exchange rate policies on Brazilian exports. EconomiA, 17, 77-95.

[62] Barrell, R., Karim, D., \& Ventouri, A. (2017). Interest rate liberalization and capital adequacy in models of financial crises. Journal of Financial Stability, 33, 261-272.

[63] Turner, D., \& Spinelli, F. (2011). Explaining the InterestRate-Growth differential underlying government debt dynamic. OECD Economics Department Working Papers, No. 919, OECD Publishing, Paris.

[64] Chughtai, M. W., Malik, M. W., \& Aftab, R. (2015). Impact of major economic variables on economic growth of Pakistan. Acta Universitatis Danubius, 11 (2), 94-106.

[65] Udoka, C. O., \& Anyingang, R. A. (2012). The effect of interest rate fluctuation on the economic growth of Nigeria. International Journal of Business and Social Science, 3 (20), 295-302.

[66] Oteng, E., David, B., \& Emmanuel, A. K. (2016). The effect of real exchange rate on economic growth in Ghana International Journal of Current Research, 8 (12), 4444844454.
[67] Raymond, A. R. (2014). An econometric analysis of effect of changes in interest rates on inflation in Nigeria. International Journal of Economics, Commerce and Management, II (10), $1-24$.

[68] Babalola, O. O., Danladi, J. D., Akomolafe, K. J., \& Ajiboye, O. P. (2015). Inflation, interest rates and economic growth in Nigeria. European Journal of Business and Management, 7 (30), 91-102.

[69] Lunsford, K. G. (2017). Productivity growth and real interest rates in the long run. Economic Commentary, no. 2017-20. Federal Reserve Bank of Cleveland.

[70] Jordaan, J. C. (2013). Impact of interest rate changes on South African GDP and households: a combined macroeconomic and social accounting matrix modelling approach. Southern African Business Review, 17 (3), 156-186.

[71] di Giovanni, J., \& Shambaugh, J. C. (2008). The impact of foreign interest rates on the economy: The role of the exchange rate regime. Journal of International Economics, 74, 341-361.

[72] Bosworth, B. P. (2014). Interest rates and economic growth: are they related? Center for Retirement Research at Boston College, working paper CRR WP 2014-8.

[73] Hansen, B. E., \& Seshadri, A. (2013). Uncovering the relationship between real interest rates and economic growth. Ann Arbor MI: University of Michigan Retirement Research Center (MRRC), Working paper WP 2013-303.

[74] Araujo, T., (2017). Does lowering the interest rate stimulate economic growth? An analysis of current macroeconomic policy. Honors in the Major Theses, 206. University of Central Florida.

[75] Faroh, A., \& Shen, H. (2015). Impact of interest rates on foreign direct investment: Case study Sierra Leone economy. International Journal of Business Management and Economic Research, 6 (1), 124-132.

[76] Central Bank of Nigeria (2017). Statistical bulletin. 